
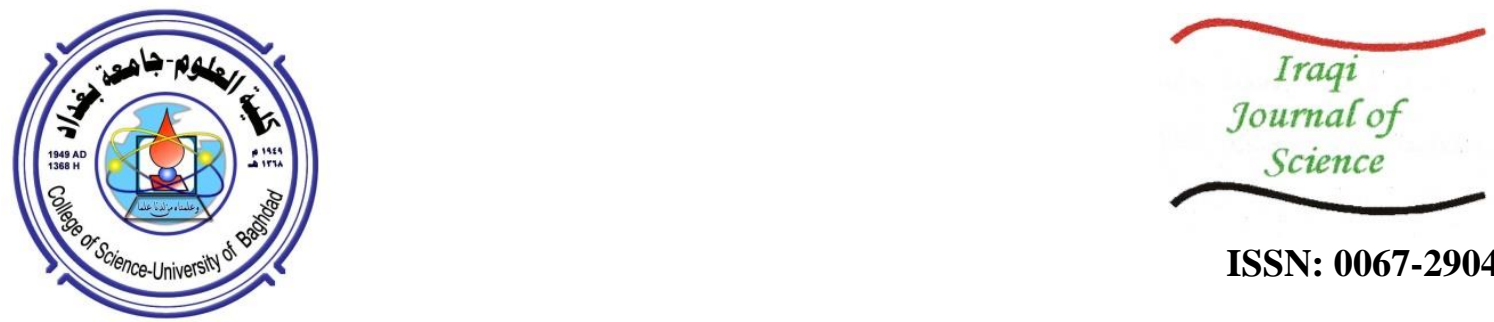

ISSN: 0067-2904

\title{
Facies Analysis and Depositional Environments of the Ubaid Formation, Western Iraq
}

\author{
Noor T. Altaee, Zaid A. Malak* \\ Department of Geology, College of Sciences, University of Mosul, Mosul, Iraq
}

Received: $22 / 2 / 2020$

Accepted: 24/10/2020

\begin{abstract}
The Early Jurassic (Liassic) sequence crops out in numerous anticlines of the high folded zone of north and north-east Iraq and in the Rutba subzone (including Ubaid Formation) in west Iraq. The present study deals with siliciclastic / carbonate rocks of the $58 \mathrm{~m}$-thick Ubaid Formation at Zor Hauran valley in south western Iraq. The formation consists of two parts; the lower part is composed of pebbly coarse sandstone and greenish to yellowish soft marl alternated with marly dolostone, while the upper part is characterized by light brown, well bedded dolostone, with stromatolite structure in some locations. Oval, light to dark brown nodules of chert are also present.

A detailed field lithological description and facies analysis of the Ubaid Formation were performed for thin sections. It is composed of five main microfacies; dolomitized mudstone, dolomitized bioclastic wackstone, dolomitized pelloidal packstone, dolomitized oolitic grainstone, and bindstone, in addition to two lithofacies: marl and pebbly sandstone. These facies reflect the deposition from the environment of the lower supratidal to intertidal zone and the encompassing shallow scaffold secured shoal - marine environment with cautious water circulation.
\end{abstract}

Keywords: Hauran Valley, Facies Analysis, Ubaid Formation, Transgressive lag, West Iraq.

$$
\begin{aligned}
& \text { التحليل ألسحني و البيئة الترسيبية لتكوين عبيد، غربي العراق } \\
& \text { نور طلال الطائي، زيد عبدالوهاب ملك الكابك، } \\
& \text { قسم علوم الأرض، كلية العلوم، جامعة الموصل، الموصل، العراق }
\end{aligned}
$$

تنكثف تتابعات عصر الجوراسي الأسفل المبكر( لياسك) في العديد من الطيات المحدبة ضمن نطاق

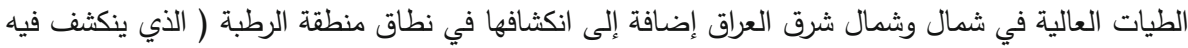

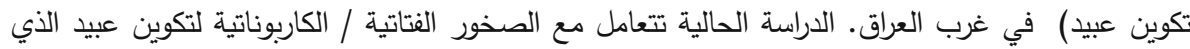

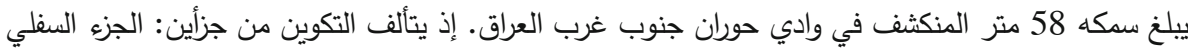

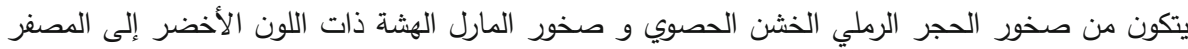

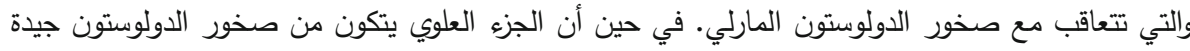

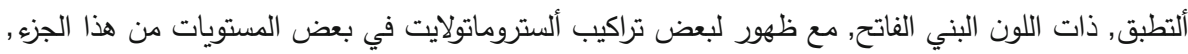

$$
\text { فضلا عن وجود عقد الصوان البيضوية, ذات اللون البني الغامق الى الفاتح. }
$$

*Email: zaidmalak@uomosul.edu.iq 


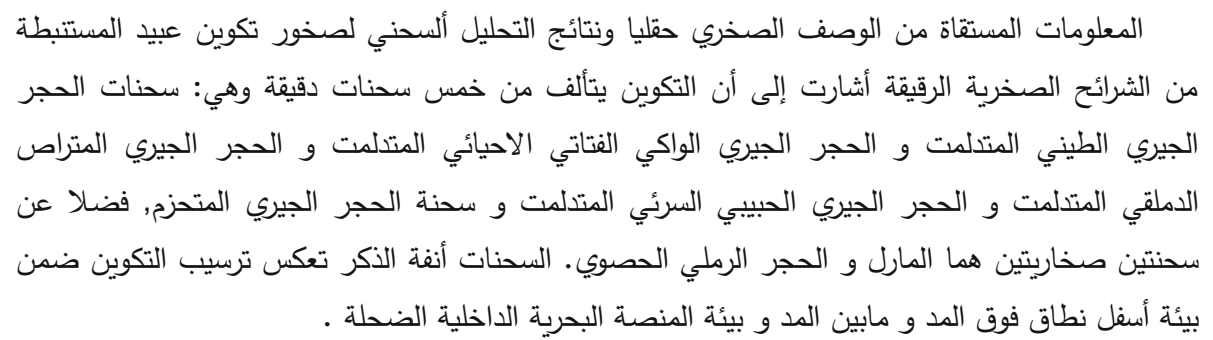

\section{Introduction}

The late Permian - Liassic Megasequence (Ap 6) was deposited on the north and east sides of the inactive Arab plate margin. The unconformity at the megasequence's lowest tough Ap6 is followed by a revived split that has occurred within that passive margin during the Mid-Late Triassic period where a highly confined intra-shelf catchment was found in the Mesopotamian. This rifting stage was followed by a slow thermal decline in the Norian-Liassic Period (Figure-1, A) [1].

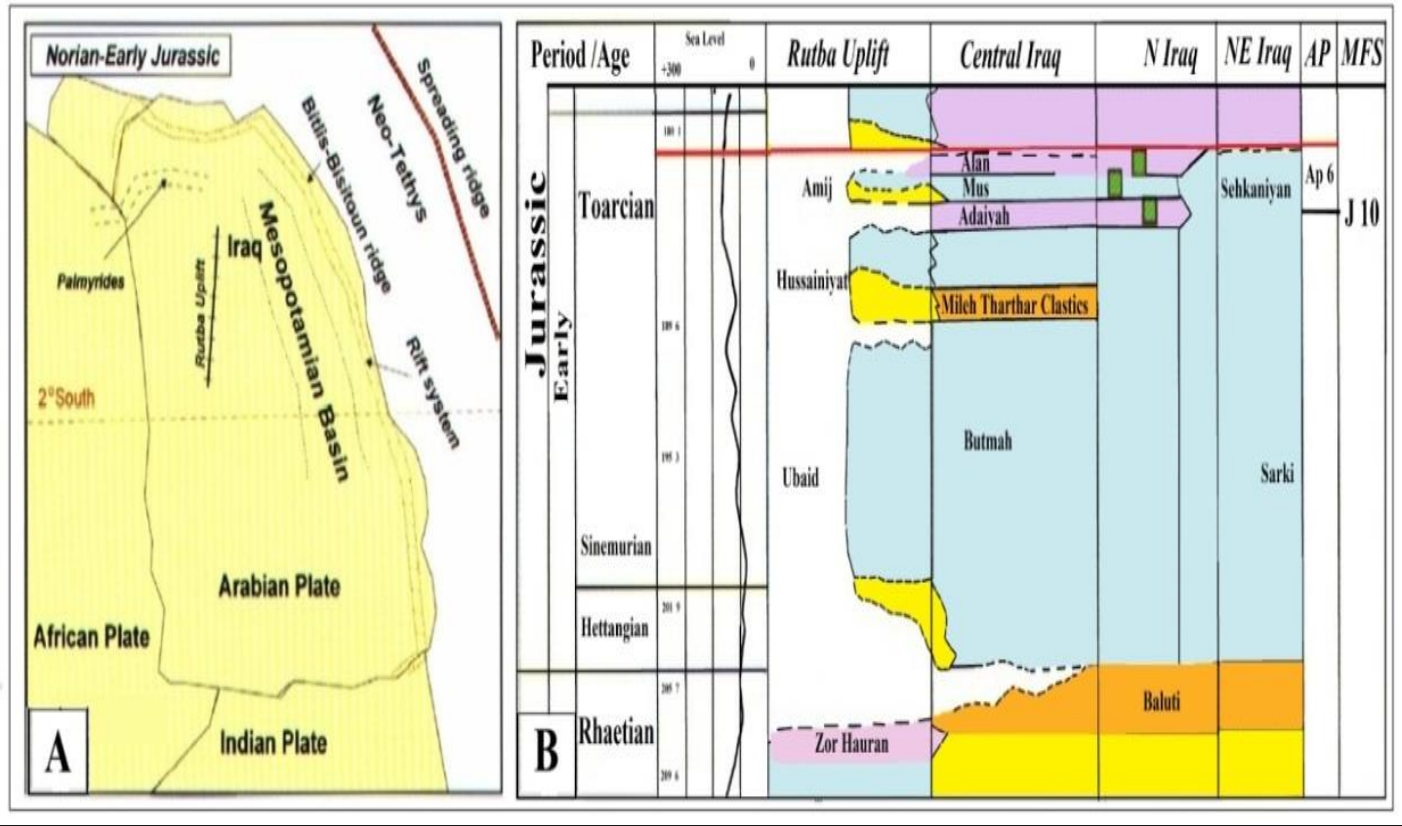

Figure 1- (A) Norian-Mid Toarcian geo-activating development of the Arabian Plate; (B) Stratigraphic correlation of Late Permian-Liassic Megasequence (Ap6) (modified after Jassim et al. $[1])$.

The Megasequence AP6 consists of three significant second order series, as follows [1]: the Late Permian - Middle Triassic, Late Triassic, and Early Jurassic. The Early Jurassic (Liassic) sequence outcrops in numerous anticlines of the high folded region of northeastern Iraq and in the Rutba subzone in the west of Iraq. The formations included in this sequence are Ubaid, Hussainiyat, and Amij Formations (clastic - carbonate inner shelf environment) in Rutba. The carbonate - evaporite inner shelf occurs in Butmah, Adaiyah, Alan, and Mus formations in an exposed section of central Iraq and the Foothill zone and the restricted lagoonal Sarki and Sehkaniyan formations in the High Folded and Balambo -Tanjero zones of north and northeast Iraq (Figure-1B). An emergent continuity of repeating transgressive - regressive pulses took place during the Liassic and are developed forward to the edge of the Rutba uplift. The sequence in west Iraq comprises three fluvial to fluvio-marine clastic cycles (deltaic) covered by the coastal carbonate shelf. The repeating toward the Mesopotamia is characterized by a sequence of inner shelf carbonate and sabkha facies [1].

Ubaid Formation in Wadi Zor Hauran area, North East Rutba, west of Iraq has been well documented in detail [2]. The Ubaid succession consists of two major parts with a total thickness of 75 $\mathrm{m}$. The lower part contains $37 \mathrm{~m}$ of pseudo-oolitic dolomitized limestone, whereas the upper part consists of limestone with abundant chert nodules with $38 \mathrm{~m}$ thickness. The age of Ubaid Formation was determined as Liassic according to microfauna [2] and its stratigraphic position is located between 
the underlying (conformable) Upper Triassic Zor Hauran Formation and the overlying (unconformable) Middle Jurassic Muhaiwir Formation.

The Ubaid Formation outcrops in a SW - NE trending belt extending about $10 \mathrm{~km}$ from east of Rutba town to Wadi Zor Hauran in the Northeast of Rutba [1], to attain about 95 m thickness. It includes the following units: (a) pebbly sandstone and red claystone overlain by ferruginous beds about $35 \mathrm{~m}$ thick. (b) dolomite and recrystallized dolomitic limestone, yellowish to light grey, with thin bedded silicified horizons and chert nodules overlain by yellowish marly limestone, which is about $40 \mathrm{~m}$ thick. (c) gypsiferous marl and recrystallized shelly limestone (stained purple to red) at the top, which is about $20 \mathrm{~m}$ thick. This is characterized by poorly preserved assemblage of Veomegaladon sp., Grammatodon sp., Mytilus ssp., Modiolus sp., and Cardita sp., which refer to the Late Triassic age. The presence of evaporites is indicated by abundant dissolution features. Jassim and Goff [1] suggested that the Ubaid Formation was deposited in shallow hypersaline lagoonal and marsh environments.

The main objective of this study is to use the petrographic study and the microfacies analysis of the Ubaid rocks to reach a conclusion of the sedimentary environment of the formation.

\section{Geological setting}

The study area is located in the south western Iraq (N $33^{\circ} 37^{\prime} 00^{\prime \prime}-32^{\circ} 56^{\prime} 00^{\prime \prime}$ and E 40 $22^{\prime} 00^{\prime \prime}$ $41^{\circ} 23^{\prime} 30^{\prime \prime}$ ) (Figure- 2). The Ubaid Formation is about 58 meters thick. The lower contact with the underlying Zor Hauran Formation is variable and marked by red carbonate layers with steep narrow channel infilled with limestone rich conglomerate. The upper contact with Hussainiyat Formation is uncomfortable and characterized by the presence of basal conglomerates topped by layers of red clay that belong to the of Hussainiyat Formation [3].

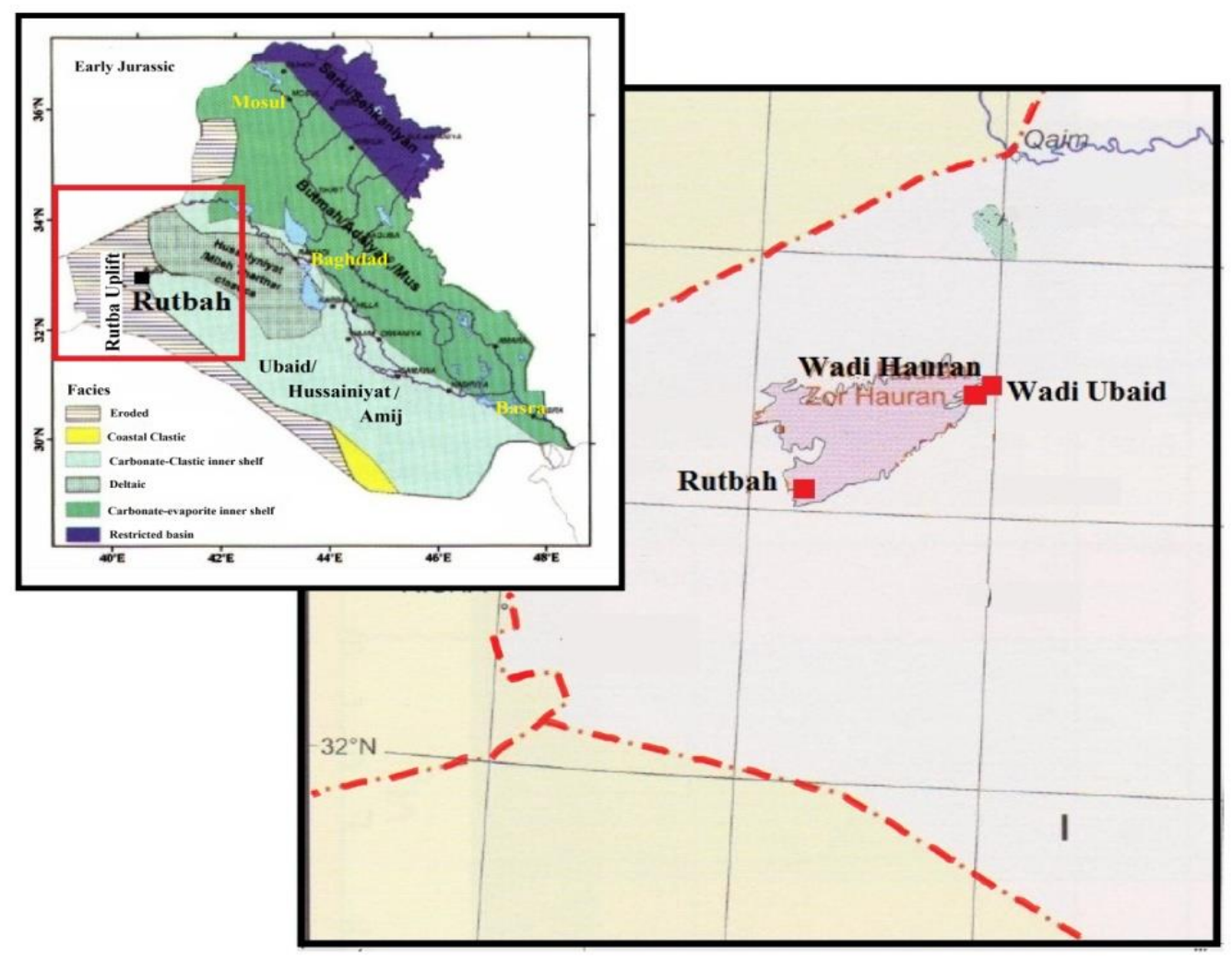

Figure 2 - The red square shows the location of the study area in South-Western Iraq [3].

\section{Description of the studied section}

The field trip and the thin section investigation were carried out to characterize the sedimentology, delineate facies, and describe the spatial distribution of this $58 \mathrm{~m}$-thick section of Ubaid Formation which is exposed at Zor Hauran valley. Two main units are identified in this study. The lower unit is consisted of $5 \mathrm{~m}$ pebbly coarse grained sandstone showing a fining - upward cycle at the lower boundary of the formation. It is followed by greenish to yellowish, soft marl, alternated with 
bioturbated marly dolostone, and calcite nodules. The upper unit is characterized by light brown, well bedded (30-50 cm thick) dolostone, with stromatolite structure in other locations and oval, light to dark brown nodules of chert (Figure-3).

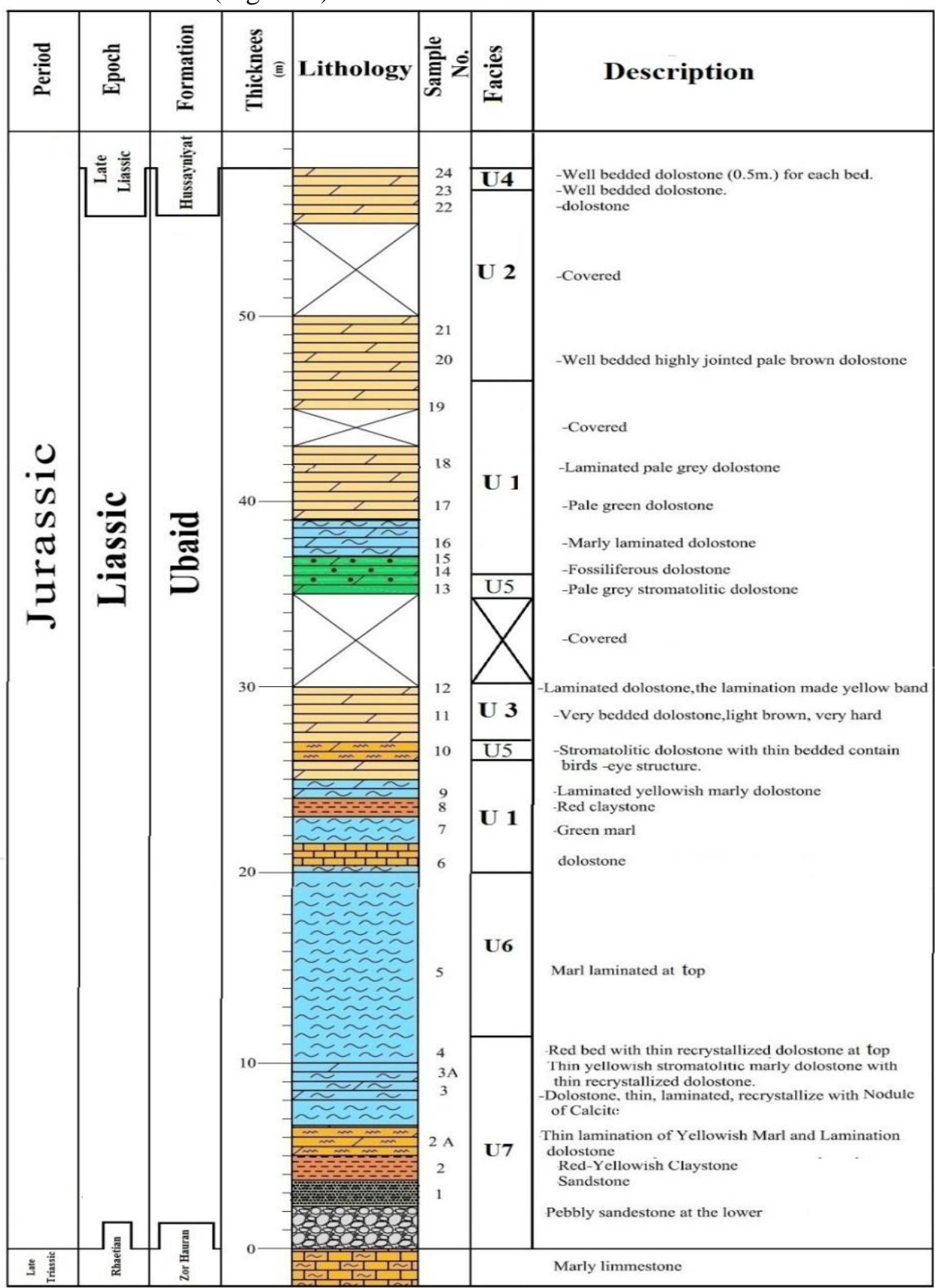

Figure 3 - Columnar section showing the lithological description of the Ubaid Formation, southwestern Iraq.

The formation's low interaction with the underlying Zor Horan Formation is inconsist-ent and commences with coarse-grained and pebbly sandstone. The upper contact of the formation is an erosional surface with the overlying Hussainiyat Formation.

This work was based on 25 samples taken from an exposed section of the Ubaid Formation to determine the facies types and their paleoenvironments based upon a detailed description of a lithological field and thin sections description. The facies types were classified by using Dunham classification [4]. The sedimentological and biological data were used to dictate and to identify the depositional environment according to Flügel [5, 6].

\section{Microfacies and Lithofacies}

The Ubaid Formation is composed of 5 main microfacies named as U1 - U5 and two lithofacies 
(U6 and U7). These microfacies reflect the paleoecology and depositional environments prevailing during the deposition of the formation.

\section{A - Microfacies analysis}

\section{A-1 - Dolomitized lime mudstone microfacies (U1)}

This microfacies is represented by pale green to yellowish dolostone and marly limestone with a thickness of about 10-15 m. It is reported from the lower and middle part of the Ubaid Formation. The facies are usually of mud promoted with infrequent allochems (Figure-4a). The allochems in this microfacies are less than $10 \%$. The matrix consists of micrite. The microfacies are affected by leaching and dolomitization, forming aphanitic and micro-textures [7]. Some fenestral fabrics are filled with gypsum crystals. According to Randazzo and Zachos [7], the homogenous dolomitization of mudstone leads to a micro-textured sutured mosaic with a solution of allochems that leads to the formation of sieve mosaic texture and aphanitic dolomite texture with secondary gypsum-infilled vugs which are common in the lower part of the Ubaid succession. This type of texture indicates a syndepositional lime mudstone dolomitization environment, according to the evaporation pumping method [7]. The lithological evidence refers to the deposition of this microfacies in a platform that is restricted to a tidal flat depositional environment $[6,8]$. This microfacies could be compared with the SMF23 within the FZ-8 and RMF 19 lime mudstone peritidal zones [5, 6]. Vaziri-Moghaddam et al. [9] considered that the occurrence of lime mudstone with gypsum lacking subaerial exposure indicates deposition in a restricted platform. Similar microfacies were reported from northwestern Zagros basin. Kangazian et al. [10] recorded such microfacies from Asmari Formation, southwest Iran, on a carbonate platform at the edge of a NW-trending foreland basin in the orogenic belt of Zagros.

4. A-2- Dolomitized bioclastic lime wackestone microfacies (U2)

This microfacies is represented by $10 \mathrm{~m}$ thick well bedded, pale brown dolostone, occurring at the upper part of the Ubaid Formation. The facies consists of up to $20 \%$ bioclasts. It consists of miliolid foraminifera, algae, echinoderm, and mollusk smithereens (Figure- 4b). The matrix is made up of micrite and microspar produced through the process of neomorphism. The facies are affected by dolomitization with a solution of allochems that leads to a sieve mosaic texture [7].

The lithological evidence indicates the deposition of this microfacies in shelf lagoon, low-energy environments below the wave base [6]. This microfacies could be compared with the SMF9-10 within FZ-7 and RMF 20 (lagoon), according to Flügel [5, 6]. It is similar to the bioclast lime wackestone microfacies reported by Hoseinzadeh et al. [11] from the Asmari Formation to west-northwest of Bandar Abbas City, southwest Iran.

\section{A-3- Dolomitized peloidal lime packstone microfacies (U3)}

This microfacies is displayed as very hard, well bedded, light brown dolostone with a thickness ranging 2-3 $\mathrm{m}$ at the middle part of the formation. Allochems percentage is higher than $60 \%$, mainly of well-preserved peloids which are spherical to oval in shape, with no internal feature composed of micrite (Figure- 4c). The matrix consists of micrite. According to Randazzo and Zachos [7], the nonhomogenous dolomitization of the facies leads to the formation of fogged mosaic fabric.

The lithological evidence refers to the accumulation of this microfacies in shallow interiors of the platform that comprises a shallow-marine protected environment, with moderate body water circulation [5] and poor connection with the open marine [12]. This microfacies could be compared with the SMF16 within FZ- 7 and FZ-8 [5, 6] and in the inner ramp settings.

\section{A- 4- Dolomitized oolitic lime grainstone microfacies (U4)}

This microfacies is displayed as a $1.5 \mathrm{~m}$-thick bed of very hard, well bedded dolostone at the upper part of the formation. Allochems percentages are higher than 75\%, mainly of well-preserved oolite, which appears as oval in shape with one or two wraps (Figure- 4d).

Skeletal and non-skeletal grains can be seen. Grains are fine-grained, of sand size, subrounded, and moderately sorted. Ooid nuclei consist of fossil fragments and lithoclast grains. The matrix consists of microspar with no micrite, which is affected by dolomitization-forming sutured mosaic fabric [7].

The lithological evidence refers to the accumulation of this microfacies as ooidal shoals near an outer platform margin with agitated water [6]. This microfacies could be compared with the SMF15 within FZ-6 [6] and RMF 29 (inner ramp shoal). The texture of this facies refers to low-energy, lowlying waters with a lot of movement and recycling of bioclasts and ooides productions. This facies is interpreted to have been deposited on high energy seafront shoal environments [13, 14]. Kangazian et al. [10] reported such microfacies from the Asmari Formation, southwest Iran. 


\section{A-5 - Boundstone facies (U5)}

This facies is recorded in the middle part of Ubaid Formation (1.4 m thick). It is characterized by laminated mode, pale grey color, and well-bedded dolostone that contain bird's-eye structure. The allochems proportion is up to $80 \%$ of the total content, portrayed by an abundance of calcareous green algae in addition to rare clastic sediments enclosed between the algal lamina. The facies was affected by leaching, cementation, dolomitization and compaction (Figure- 4e).

The presence of calcareous green algae suggests a marine-origin depositional environment, specified by shallow-water that forms the upper euphotic zone (from the surface of the sea to $-25 \mathrm{~m}$ ) [15]. The bird's-eye structures are interpreted as former gas-bubble voids of dissolution pores or amalgamated gas-bubble voids [16]. In addition, clastic sediments are present in the matrix that indicates deposition in sheltered basins within a tide-dominated marine environment. The presence of even laminations of calcareous green algal limestone is associated with the presence of bird's-eye structure and clastic sediment lamina which represents deposition in a lower supratidal carbonate platform to intertidal zone.

This microfacies is comparable with the RMF23 [5] and similar to the microfacies which occur in the top part of the Asmari Formation [10].

\section{B - Lithofacies analysis}

\section{B - 1 - Marl lithofacies (U6)}

The facies are made of soft green to dark grey marl, with thickness of about $10 \mathrm{~m}$, embracing thin lamination of hard yellowish marly dolostone. This facies were deposited in a deep shelf marine environment [5].

4. B - 2 - Pebbly sandstone lithofacies (U7)

The facies consist of $5 \mathrm{~m}$-thick pebbly coarse sandstone showing fining of upward trend at the lower part of the formation. The pebbles and cobbles are ranging from 5 to $10 \mathrm{~cm}$ in diameter, some of which being angular. The cementing material includes calcite, dolomite, silica, and iron oxides (Figure-4f).

Lenses of pebbles and coarse sandstone show fining upwards trend that reflects shallow river channels [17]. In this environment, the coarse sediments are deposited at the channel floor of the river as a channel lag [18]. Channels with shallow and wide sides appear in the river and have poorly channelization stream system at the lower end of the river [19] when it concourses with the shallow part of the shoreline. These channelization stream systems are located beneath or near to the base of many transgressive deposits in cases where the transgressive shoreline is strong or moderate, with probable carbonate cement and pebble. Transgressive shorelines may be embayed, if they consist of a lake or an estuary and have control and deposits on the river [20]. Thus, this facies can be considered as a transgressive lag.
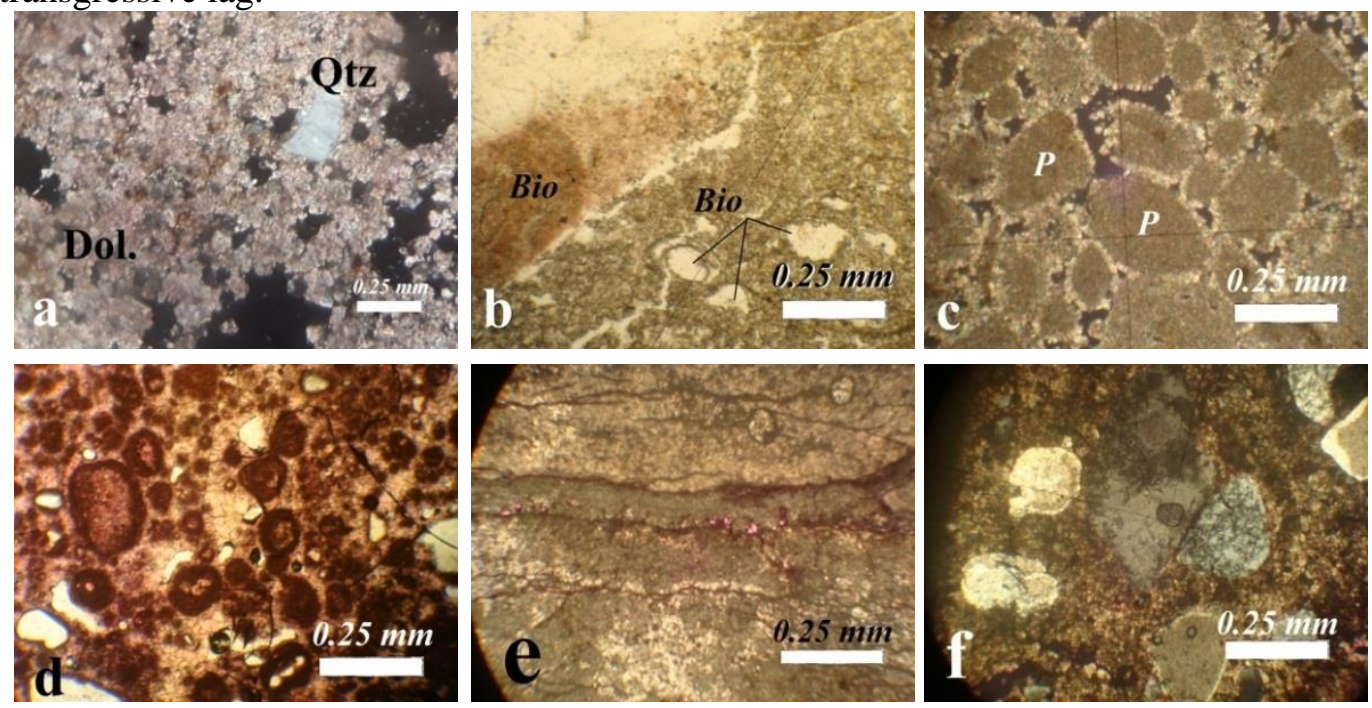

Figure 4 - (a) leaching and dolomitization (sieve textured suture); (b) dolomitized bioclastic (bio) lime wackestone microfacies (U2); (c) well preserved peloids (P), spherical to oval in shape; (d) well preserved Oolite; (e) algal lamination in boundstone microfacies; (f) coarse sand grains with carbonate cement. 


\section{Discussion}

Vertical facie's tract changes can be related to eustacy, tectonics, and sediment. The formation is initiated by the appearance of pebbly sandstone lithofacies (U7), showing fining upwards that reflects transgressive lag. The progradation of transgressive lag reflects sea level lowstand, which is attributed to the tectonic activeness and sedimentary processes. It directly occurs above the unconformable contact between the Ubaid and the underlained Zor Hauran Formations. It is followed by thick beds of marl which sign local deepening in the depositional environment and transferred from the land environments to the marine environments. The evidence allows for recognizing transgressive deposits and a gradual shift of facies landward or a facies deepening upward that culminates in a maximum flood surface.

The previous lithofacies associate with the dolomitized lime mudstone microfacies (U1) with fenestral fabric. Rare fossiliferous content refers to supratidal setting and suggests low energy conditions. The tidal flat depositional environment of the last facies may attend the development of the basin kind of local shallowing in some parts of the major depositional basin, reflected by the presence of the laminations of calcareous green algae limestone and clastic sediments layers (facies U5). This could have grown all along the lower supratidal to intertidal zones of protected areas of the upper intertidal zone in bights or confined basins [21].

All the previous facies are capped by dolomitized pelloidal lime packstone microfacies (U3) at the middle part of the formation. Well-preserved peloids are present, with a high content of matrix that consists of micrite, reflecting an indoor shallow platform that consists of shallow-marine protected area with good circulation of water [6]. This facies forms a retrogradational stacking pattern [22].

The repetition of the occurrence and concealment of some of the above facies (U1, U5) reflects the fluctuation in the sea level. At the upper part, the formation is wrapped by the deposition of the facies $\mathrm{U} 1, \mathrm{U} 2$, and $\mathrm{U} 4$, which display a shallow environment at the beginning and then alter upwards to the deep environment, as ooid shoals near an outer platform margin with agitated water. The oolitic lime grainstone microfacies with bioclast-peloid-bearing packstone may indicate deposition to lower intertidal shallow subtidal layers [23]. Changes in vertical facies in the section are interpreted as caused by fluctuations in the sea-level or topography of the depositional environment, but they prevail the shallow marine depositional environment (Figure-5).

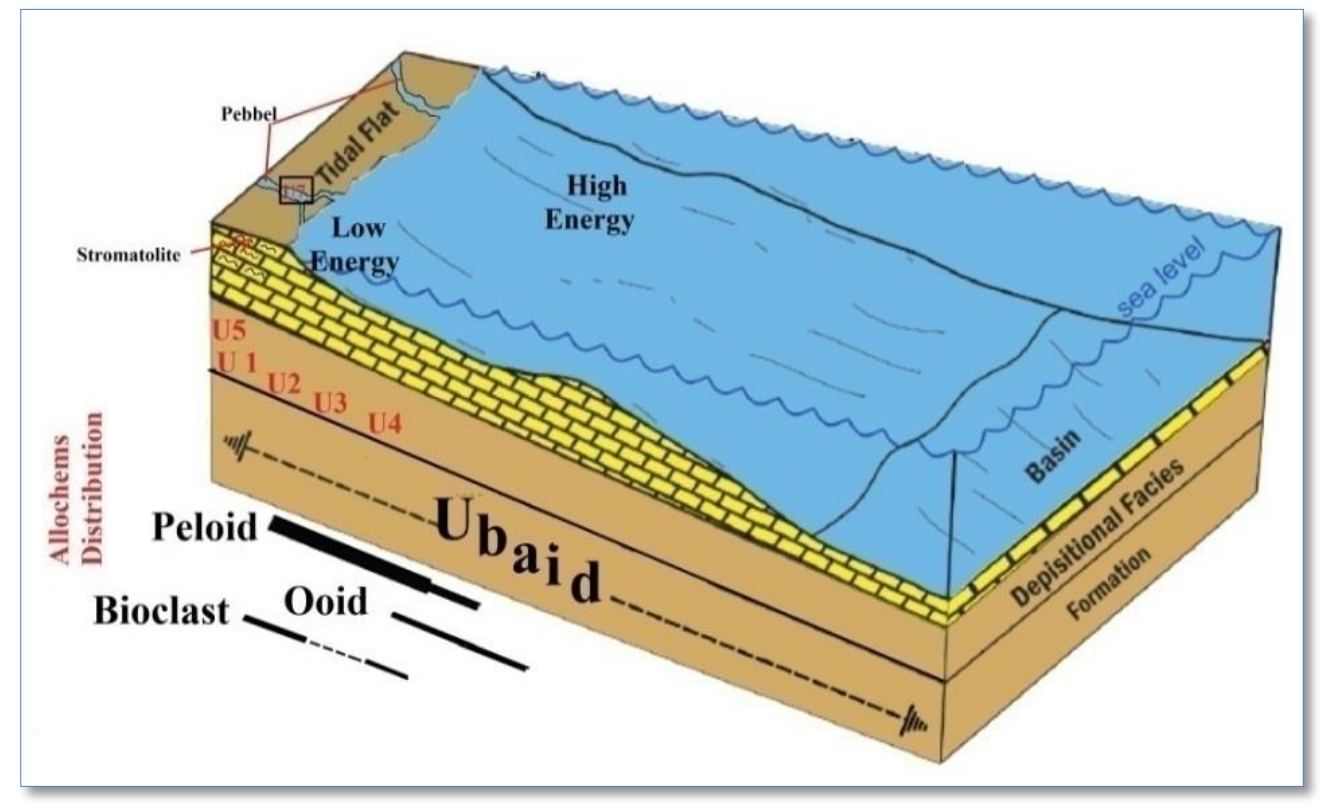

Figure 5 - Schematic representation showing a block diagram of the depositional environment of Ubaid Formation.

The tectonic activity may reflect the local blocking and thermal subsidence during the Early Jurassic, which affected the moderately stable Rutba area and concussed the depositional environments and sequence stratigraphy development in the basin. Eustacy has been one of the main parameters which also affect sequence creation. Thus, the relative sea level is a result of total 
subsidence and eustacy; these two factors provide the necessary accommodation for accumulation of sediment [24].

\section{Conclusions}

This study was based on an exposed section of Ubaid Formation underlying the Zor Hauran Formation, which is a variable section that appeared as red carbonate layers with steep and lag transgression of limestone conglomerate, whilst the upper touch with Hussainiyat Formation is disconformity. The formation at the base consists of $5 \mathrm{~m}$ pebbly coarse sandstone showing fining upward, overlain by $25 \mathrm{~m}$ greenish to yellowish soft marl, alternated with marly dolostone. Nodules of calcite and bioturbation are present. The upper section of the formation is characterized by light brown, well bedded dolostone, with a stromatolite structure in some locations, while oval nodules of chert were also present. Five main microfacies are recognized within the Ubaid Formation; dolomitized lime mudstone microfacies, dolomitized bioclastic lime wackestone microfacies, dolomitized pelloidal lime packstone microfacies, dolomitized oolitic lime grainstone microfacies, and bindstone facies and two lithofacies (marl and pebbly sandstone). These facies indicate the deposition from lower supratidal to intertidal zone and interiors of shallow platform consisting of protected shallow-marine environments with moderate circulation of water.

\section{Acknowledgments}

The authors are very grateful to the University of Mosul / College of Sciences for the provision of their facilities, which aided to improve the quality of this work.

\section{References}

1. Jassim, S. Z. and Goff J.C., 2006. Geology of Iraq. Prague and Moravian Museum, Brno, Dolen, $341 \mathrm{p}$.

2. Van Bellen, R. C.; Dunnington, R.; Wetzel and Morton, D. M., 1959. Iraq. lexique stratigraphique internationale, III, Asie, 10a, 333 p.

3. Al-Singery, A. A., 1987. Stratigraphy of the Jurassic system, Rutba area. Un. Published thesis, University of Baghdad. 211p.

4. Dunham, R.J., 1962. Classification of carbonates rocks according to the depositional texture. In: Ham, W.E. (Eds.) Classification of carbonate rock. American Association of Petroleum Geologists, Memoir (1): 108-121.

5. Flügel, E., 2004. Microfacies of carbonate rocks, analysis, interpretation and application, Springer, Berlin, $976 \mathrm{p}$.

6. Flügel, E., 2010. microfacies of carbonate rocks, Springer, Verlag, Berlin, Heidelberg, 976p.

7. Randazzo, A. F. and Zachos, L. G., 1984. Classification and description of dolomite fabrics of rocks from the Floridian aquifer. Sedimentary Geology, 37: 151 - 162.

8. Amin, M. A., Al-Mutwali, M. M. and Thannon, T. A., 2005. Microfacies \& paleoenvironment of Sinjar Formation (Paleocene - Early Eocene), Sinjar Area. Rafidain Journal Science, Geology, Special Issue, 16: 1 - 20.

9. Vaziri-Moghaddam, H.; Seyrafian, A.; Taheri, A. and Motiei, H., 2010. Oligocene-Miocene ramp system (Asmari Formation) in the NW of the Zagros Basin, Iran: Microfacies, paleoenvironment and depositional sequence. Revista Mexicana de Ciencias Geológicas, 27: 56-71.

10. Kangazian, A. and Pasandideh M., 2016. Sedimentary environment and sequence stratigraphy of the Asmari Formation at khaviz anticline, Zagros Mountains, Southwest Iran. Open Journal of Geology, 6: 87-102.

11. Hoseinzadeh, M.; Daneshian, J.; Moallemi, S. A, and Solgi, A., 2015. Facies analysis and depositional environment of the Oligocene-Miocene Asmari Formation, Bandar abbas hinterland, Iran. Open Journal of Geology, 5: 175-187.

12. Tomasovych, A., 2004. Microfacies and depositional environment of an upper triassic intraplatform carbonate basin: the fatric unit of West Carpathians (Slovakia). Facies. 50: 77-105.

13. Adabi, M.H., Salehi, M.A. and Ghabeishavi, A., 2010. Depositional environment, sequence stratigraphy and geochemistry of lower Cretaceous carbonates (Fahliyan Formation), south-west Iran. Journal of Asian Earth Sciences. 39: 148-160. 
14. Sardarabadi, S.; Jahani, D. and Ghadimvand; N. K., 2016. Facies, Depositional environment and Diagenesis of the Qom Formation in Rameh Section (Northeastern Garmsar). Open Journal of Geology, 6: 1240-1256.

15. Granier, B., 2012. The contribution of calcareous green algae to the production of limestones: a review. Geodiversitas, 34 (1): 35-60.

16. Wet, C. B.; Moser, A. C.; Oxman, K. L. and Peck, E. P., 2016. Semiarid Climate and Cyclic Carbonates-Deposition and Diagenesis of the Middle Cambrian Buffalo Springs Formation, Morgantown, Pennsylvania. Pennsylvania Geology. 46 (3): 1-20.

17. Pavelic, D. and Kovacic, M., 1999. Lower Miocene alluvial deposits of the Pozeska Mt. (Pannonian Basin, Northern Croatia): cycles, megacycles and tectonic implications. Geologia Croatia, 52 (1): 67 - 76.

18. Noda, A.; Takeuchi, M. and Adachi, M., 2002. Fan deltaic - to - fluvial sedimentation of the Middle Jurassic Murihiku Terrane, Southland, New Zealand. New Zealand Journal of Geology and Geophysics, 45:297 - 312.

19. Zielinski, T. and Gozdzikm, J., 2001. Palaeoenvironmental interpretation of a Pleistocene alluvial succession in central Poland: sedimentary facies analysis as a tool for palaeoclimatic inferences. Boreas, 30: 240 - 253.

20. Cattaneo, A. and steel R. J., 2003. Transgressive deposits: a review of their variability. EarthScience Reviews. 62: 187-228.

21. Daoud, H. S. and Karim K. H., 2010. Types of stromatolites in the Barsarin Formation (Late jurrasic), Barzinja area, Northeast Iraq. Iraqi Bulletin of Geology and Mining. 6 (1): 47 - 57.

22. Richardt, N. and Wilmsen, M., 2014. Sequence Stratigraphy of the Lower Upper Cretaceous Elbtal Group (Cenomanian-Turonian of Saxony, Germany). In: Rocha R., Pais J., Kullberg J., Finney S. (eds) STRATI 2013. Springer Geology. Springer, Cham. 1325p.

23. Gandian, A., 2012. Tectonic control on the sedimentary architecture of Early Mesozoic mixed siliciclastic-carbonate Pseudoverrucano successions (southern Tuscany, Italy). Ital. J. Geosci. (Boll. Soc. Geol. It.), 131(1): 77-94.

24. Gayara, A. D. and Al-Gibouri, A. S., 2015. Sequence stratigraphic analysis of the Lower Jurassic succession, Western Iraq. Arabian Journal of Geosciences, 8(8):5833-5843. 